\title{
A Lot of Promise for ZnO-5FU Nanoparticles Cytotoxicity against Breast Cancer Cell Lines
}

\section{Sanad $\mathrm{F}^{1 *}$, Nabih $\mathrm{S}^{2}$ and Goda $\mathrm{MA}^{3}$}

${ }^{1}$ Chemistry Department, Faculty of science, Ain Shams University, Egypt

${ }^{2}$ Basic Science Department, Modern Academy for Engineering and Technology, Maadi, Egypt

${ }^{3}$ Biochemistry Department, Faculty of Science, Mansoura University, Egypt

\begin{abstract}
In this study we present an approach for new modification of 5-FU drug, which widely used for treatment of cancer by inhibiting essential biological processes. Recently understanding of the treating mechanism of 5-FU has led to the development of new ways that raises its activity. Herein, we modify the drug function by combination with $\mathrm{ZnO}$ which get a lot of attention in the past 10 years in the field of anticancer drug development. Anticancer activity of $\mathrm{ZnO}$ reveals to production of Reactive Oxygen and ions. Zinc Oxide were designed by Sol-Gel. X-ray, High resolution transition electron microscope and scanning electron microscope used to characterize the structure and morphology of samples. DPPH, SOD and GPx radical scavenging activity applied to investigate the antioxidant activity. Cytotoxicity of MCF-7 was determined by MTT assay, flow cytometry and RT-PCR which confirms that ( $\mathrm{ZnO}-5-\mathrm{FU})$ will be promising efficient drug for treatment of breast cancer.
\end{abstract}

Keywords: 5-FU; ZnO; Nano particles; Cell cycle analysis; Apoptosis; BET; MCF-7

\section{Introduction}

Breast Cancer is one of the most common cancers among women. Statics indicate that the number of cases is about 10 million in 2002 and expected to be 15 million by 2025 . The Major of these cases occurring in developing nations. Different parameters may increase the development of breast cancer disease includes genetic [1,2], environmental [3] and physiological factors $[4,5]$. Recently, statics shows that the risk of the disease has risen in all countries by $2 \%$ every year. Chemotherapy [6,7], hormone therapy $[8,9]$ and targeted therapy $[10,11]$ are summarizes all ideas of treating breast cancer, but each method has its own drawbacks. chemotherapy has very acute side effects [12], hormone and targeted therapy are selective to certain types of cancer, In this study we present an approach for new modification of 5-FU drug, which widely used as anticancer by inhibiting essential biological processes [13], or by being incorporated into molecules like DNA and disturbing their functions $[14,15]$. Recently, understanding of 5-FU way of killing of MCF-7 has led to new modifications that increases its anticancer activity [16]. Otherwise, the resistance of the drug remains a great limitation to the clinical trials of 5-fluorouracil. Herein, we modify the drug function by combination with nanoparticles which get a lot of attention in the past 10 years in the field of anticancer drug development. In 2008 scientists modified 5-FU to be more effective by combination with polymer which has biodegradable characteristics against cancer disease [17-20]. Other study includes the combination treatment of oxaliplatin and 5-fluorouracil [21]. Researchers at Lincoln University College at Malaysia present a study of Nano drug delivery strategy of 5-fluorouracil for the treatment of colorectal cancer [22]. Many other studies in the past 10 years about Nano-carrier based Drugs: The Future Promise for Treatment of Breast Cancer and Substances in the nano scale consisting of human drugs which suggested as a promising strategy for targeted drug delivery to cancer cells [23-30]. We prepare ZnO Nanoparticles by Sol-Gel method using CTAB as pore directing agent [31]. XRD used to investigate the structure of synthesized nanoparticles of $\mathrm{ZnO}$. HRTEM and SEM used to explain the morphology and confirm the nanostructure. Antioxidant activity investigated by DPPH, SOD and GPx. Cytotoxicity of MCF7 was determined by MTT assay, flow cytometry and RT-PCR; all obtained results confirm that (ZnO-5-FU) an economic efficient drug for treatment of breast cancer.

\section{Methods}

Zinc oxide $(\mathrm{ZnO})$ nanoparticles was prepared by sol gel method which widely used for designing nanoparticles, hydrolyzing of Zinc acetate $\left(\mathrm{ZnAC}_{2} \cdot 2 \mathrm{H}_{2} \mathrm{O}\right)$ as $\mathrm{Zn}$ source in a mixture with absolute ethanol as solvent, ammonia solution $\left(\mathrm{NH}_{4} \mathrm{OH}\right)$ as precipitant and Cetyltrimethylammonium bromide $(\mathrm{CTAB})$ as pore directing and capping agent, in a beaker mix $400 \mathrm{ml}$ of ethyl alcohol $\left(\mathrm{C}_{2} \mathrm{H}_{5} \mathrm{OH}\right)$, $70 \mathrm{~g}$ of zinc acetate and $20 \mathrm{ml}$ of $(10 \% \mathrm{w} / \mathrm{v})$ of CTAB and stirred for 60 minutes until complete homogeneity, add ammonium hydroxide solution until neutral point $(\mathrm{pH}=7)$, the reaction solution still clear for a while until formation of gel then solution becomes turbid and completed in $2 \mathrm{~h}$. The resulting gel was dried for 3 days at $90^{\circ} \mathrm{C}$ and then calcined for $2 \mathrm{~h}$ at $700^{\circ} \mathrm{C}$. 5-FU Nanoparticles preparation began by passing $\mathrm{CO}_{2}$ through a cooling device and delivering it to a $0.6 \mathrm{~L}$ vessel by a syringe pump until pressure reached 100 bar. Vessel was kept in an oven at $70^{\circ} \mathrm{C}$ for $3 \mathrm{~h}$. Firstly, size of 5-FU was decreased by using a ball mill. In a mixture add $3 \mathrm{ml}$ of methanol and $3 \mathrm{ml}$ of dichloromethane as solvents were selected for synthesis $5 \mathrm{mg} / \mathrm{mL}$ of the solutions. $1 \mathrm{~mL} / \mathrm{min}$ of solution of $5-\mathrm{FU}$ was delivered to the vessel and $20 \mathrm{~mL} / \mathrm{min} \mathrm{CO}$ flow. During this operation, particles were precipitated on the walls of the vessel. This stage took about two hours until we collected the solid nanoparticles. ZnO-5-FU Nanoparticles prepared by capping definite amount of hexagonal $\mathrm{ZnO}$ Nanoparticles with 5-FU drug in $100 \mathrm{ml}$ distilled water and continuous steering at $25^{\circ} \mathrm{C}$ through

*Corresponding author: Mohamed Fathi Sanad, Chemistry Department, Faculty of Science, Ain Shams University, Egypt, Tel: 201018423851; E-mail: chemist_houner@yahoo.com

Received: January 24, 2017; Accepted: February 23, 2018; Published: February 26, 2018

Citation: Sanad F, Nabih S, Goda MA (2018) A Lot of Promise for ZnO-5FU Nanoparticles Cytotoxicity against Breast Cancer Cell Lines. J Nanomed Nanotechnol 9: 486. doi: 10.4172/2157-7439.1000486

Copyright: $\odot 2018$ Sanad F, et al. This is an open-access article distributed under the terms of the Creative Commons Attribution License, which permits unrestricted use, distribution, and reproduction in any medium, provided the original author and source are credited. 
physical adsorption leading to the very stable structure of $1,3,7,10 \%$ ZnO:5-FU. Samples were loaded into the P Analytical X'PERT MPD diffractometer using $(\mathrm{Cu}[\mathrm{Ka} 1 / \mathrm{Ka} 2])$ radiation, the X-ray diffraction peaks were appeared, the diffraction angle range from $20^{\circ} \mathrm{C}$ to $100^{\circ} \mathrm{C}$ with a step of $0.02^{\circ} \mathrm{C}$ and integration time of $3(\mathrm{~s} / \mathrm{step})$, the diffraction peaks have been treated with the Rietveld refinement way using the (MAUD) program, the imperfections were detected with a sample of LaB6 calibrated against NIST SRM-640b. Adsorption isotherms of $\mathrm{N}_{2}$ at $77 \mathrm{~K}$ were detected using volumetric instruments connected to a vacuum for outgassing until reach $10^{-5}$ Torr, desorption isotherm for measuring the pore-size distribution using the Barret Joyner Halender $(\mathrm{BJH})$ way. Morphology of the samples was studied by Field emission scanning electron microscopy (FESEM), were detected on a (FESEM JEOL 6340) electron microscope equipped with an energy dispersive $\mathrm{X}$-ray analysis (EDX) to detect the elemental structure of the system. High resolution transmission electron microscopy (HRTEM) used to confirm the nanostructure of the prepared samples, where images were detected on a HRTEM JEOL 6340 electron microscope. Antioxidant activity of used samples was studied via 3 reagents 1, 1-diphenyl-2picrylhydrazyl (DPPH), Glutathione peroxidase (GPx) and Superoxide Dismutase (SOD) free radicals. $2 \mathrm{ml}$ of $0.2 \mathrm{mM}$ methanolic solution of DPPH was added to $100 \mu \mathrm{L}$ of each sample and allowed to react at room temperature After 20 minutes. The absorbance (A) values were measured by UV-VS spectrophotometer and using methanol as blank, $400 \mu \mathrm{L}$ of $0.2 \mathrm{mM}$ DPPH solution in $2 \mathrm{~mL}$ methanol as (-) control and $200 \mu \mathrm{L}$ of Ascorbic acid was taken as $(+)$ control at $(\lambda=492 \mathrm{~nm})$. Inhibition\% was calculated using by the following equation:

$$
\% \text { Inhibition }=\frac{\mathrm{A} 0-\mathrm{A} 1}{\mathrm{~A} 0} \times 100
$$

Where ' $A_{0}$ ' was the control absorbance and ' $A_{1}$ ' was the absorbance in the presence of the samples. Glutathione peroxidase (GPx) reagent prepared by mixing $2 \mathrm{ml}$ of $100 \mathrm{mM}$ of Phosphate Buffer at $\mathrm{pH} \mathrm{7,0.2}$ $\mathrm{ml}$ of $24 \mu \mathrm{Mol} \geq 12 \mathrm{U} 4.8 \mu \mathrm{Mol}$ of lyophilized reagent, Glutathione (GSH), Glutathione reductase, $\beta$-nicotinamide-adenine dinucleotide phosphate reduced (NADPH), $0.2 \mathrm{ml}$ of each sample and $0.1 \mathrm{ml}$ of $\mathrm{H}_{2} \mathrm{O}_{2}$ as sample and mix $2 \mathrm{ml}$ of $50 \mathrm{mM}$ of Phosphate Buffer ( $\mathrm{pH} 7$ ), $0.2 \mathrm{ml}$ of $24 \mu \mathrm{Mol} \geq 12 \mathrm{U} 4.8 \mu \mathrm{Mol}$ of lyophilized reagent, Glutathione (GSH), Glutathione reductase, $\beta$-nicotinamide-adenine dinucleotide phosphate reduced (NADPH), $0.2 \mathrm{ml}$ of distilled water and $0.2 \mathrm{ml}$ of $\mathrm{H}_{2} \mathrm{O}_{2}$ as control.Superoxide Dismutase (SOD) working reagent prepared by mixing $20 \mathrm{ml}$ of $50 \mathrm{mM}$ of Phosphate Buffer adjusted at (pH 8), $2 \mathrm{ml} 0.2 \mathrm{mM}$ of Nitroblue tetrazolium (NBT) and $2 \mathrm{ml}$ of 0.2 $\mathrm{mM}$ of NADH. In a mixture add $1 \mathrm{ml}$ of working reagent with $0.1 \mathrm{ml}$ distilled water as control, samples prepared by $1 \mathrm{ml}$ of working reagent and $0.1 \mathrm{ml}$ of each sample, after mixing of solutions we add $0.2 \mathrm{ml}$ of $0.2 \mathrm{mM}$ of Phenazine methosulfate (PMS) to the control and samples, finally Measure the amount increased in absorbance $(\Delta \mathrm{A})$ at $(560 \mathrm{~nm})$ for control and for sample room temperature. MCF-7 were cultured in RPMI supplemented with medium containing $10 \%$ fetal bovine serum (FBS) and antibiotic/antimycotic ( $1 \%$ penicillin/streptomycin). The cells were maintained at temperature of $37^{\circ} \mathrm{C}$, about $5 \%$ of $\mathrm{CO}_{2}$, about $95 \%$ of air and $100 \%$ relative humidity. Maintenance cultures were passaged weekly, and the culture medium was changed twice a week. MTT is salt which soluble in $\mathrm{H}_{2} \mathrm{O}$ which degraded via succinatedehydrogenase which considered as mitochondrial enzyme in cells. This enzyme breaks the tetrazolium ring, converting the MTT to an insoluble formazan. Therefore, the amount of formazan is directly proportional to the number of viable cells. MTT cytotoxicity investigation was used to examine the effect of prepared samples of ( $\mathrm{ZnO}-5-\mathrm{FU})$ on MCF7 cells, either single or in combination with 5-FU. (5, 2.5, 1.25, 0.64,
$0.32,0.16,0.08,0.04) \mu \mathrm{g} / \mathrm{ml}$ added for cytotoxicity determination using colorimetric MTT, each concentration was tested in triplicates. Cells were distributed to 96 -well plate and incubated at $37^{\circ} \mathrm{C}$ with $5 \% \mathrm{CO}_{2}$ with MTT in $50 \mu \mathrm{l} /$ well of $0.05 \mathrm{mg} / \mathrm{ml}$ phosphate buffered saline (PBS) for $48 \mathrm{~h}$. Produced Formazan crystals were solubilized in $100 \mu \mathrm{l}$ of DMSO and measured the absorbance (A) at $570 \mathrm{~nm}$ using ELISA plate reader. Optical density was plotted against the concentration and the $\mathrm{IC}_{50}$ of each fraction and drug was calculated by using MASTER PLEX 2010 software. The percentage cell viability was then calculated with respect to control as follows:

$$
\begin{aligned}
& \% \text { Cell viability }=[\mathrm{A}]_{\mathrm{T} /}[\mathrm{A}]_{\mathrm{c}} \times 100 \\
& \% \text { Cell inhibition }=100-[\mathrm{A}]_{\mathrm{T}} /[\mathrm{A}]_{\mathrm{c}} \times 100
\end{aligned}
$$

Apoptosis is characterized by the translocation of phospholipid phosphatidyl serine from the inner leaflet of the plasma membrane to the cell surface, and can be assessed using an Annexin V-fluorescein isothiocyanate (FITC) labeled annexin V (annexin V-FITC) antibody. Briefly, MCF-7 cells were seeded in a 6-well plate with a concentration of $2.4 \times 10^{5}$ cells $/ \mathrm{ml}$. Incubated the plate for 1 day. Until all cells attachment step is completed. After incubation, the seeded cells were treated with the $\mathrm{IC}_{50}$ concentration value of bird chili fractions and treated with or without the indicated concentrations of $10 \mu \mathrm{g} / \mathrm{ml} 5-\mathrm{FU}$. Incubate the plate again for 72 hours. $5 \mu \mathrm{L}$ of FITC Annexin V and $6 \mu \mathrm{L}$ of Propidium Iodide were added to stain the cells suspension and allowed to stand in a dark place at room temperature for $20 \mathrm{~min}$. afterwards; the stained cells were analyzed by flow cytometry machine. The cell cycle analysis was carried out using TEST PLUS DNA Reagent Kit. The cells were seeded at a concentration of $\left(2.4 \times 10^{5}\right.$ cells $\left./ \mathrm{mL}\right)$ in a 6 well-plate and incubated for one day; the seeded cells were treated with $\mathrm{IC}_{50}$ concentration of $\mathrm{ZnO}-5-\mathrm{FU}$ incubated for $72 \mathrm{~h}$. After trypsinization, cells were collected and $250 \mu \mathrm{L}$ of trypsin buffer was added. After $20 \mathrm{~min}$ of incubation at $25^{\circ} \mathrm{C}, 200 \mu \mathrm{L}$ of solution (trypsin inhibitor and RNase buffer) were added and the cell suspension was mixed gently. A further $10 \mathrm{~min}$ of incubation time at $25^{\circ} \mathrm{C}$ were required before a $200 \mu \mathrm{L}$ of cold solution propidium iodide stain solution were added to stain the cells. The mixture solutions were incubated for another $20 \mathrm{~min}$ in the dark on ice before analyzed by flow cytometer machine. We apply the cell cycle analysis for all fractions with and without 5-FU. Total RNA was isolated from cultured MCF-7 cells after treatment with phosphate buffered saline PBS (control) for $72 \mathrm{~h}$. RNA from each sample was extracted and isolated using t-RNA isolation kit based on the manufacturer's protocol (Qiagen, Germany). Briefly, reverse transcription reaction was carried out using Maxima $H$ minus firststrand cDNA synthesis kit (Thermo Fischer Scientific, Australia) with $2 \mu \mathrm{g}$ of total RNA diluted in $40 \mu \mathrm{l}$ oligo (dT) primers and cycled at $50^{\circ} \mathrm{C}$ for $40 \mathrm{~min}, 90^{\circ} \mathrm{C}$ for $5 \mathrm{~min}$, and $5^{\circ} \mathrm{C}$ for $5 \mathrm{~min}$. The resulting cDNA was subjected to Polymerase Chain Reaction amplification in a total volume of $10 \mu \mathrm{l}$ of the reaction of $2 x Q u a n t i T e c t$ SYBR Green PCR Master Mixture. The cycling conditions were as follows, PCR initial heat activation for $14 \mathrm{~min}$ at $95^{\circ} \mathrm{C}$ for 1 cycle, denaturation step at $94^{\circ} \mathrm{C}$ for $15 \mathrm{~s}$ for 45 cycles, annealing at $50^{\circ} \mathrm{C}$ for $30 \mathrm{~s}$ for 45 cycles, extension at $72^{\circ} \mathrm{C}$ for $30 \mathrm{~s}$ for $45 \mathrm{cycles}$, data acquisition $95^{\circ} \mathrm{C}$ for $15 \mathrm{~s}$ for 1 cycle, and final extension at $60^{\circ} \mathrm{C}$ for $60 \mathrm{~s}$ for 1 cycle. Results were recorded as mean \pm standard deviation with each fraction being tested in three replicates.

\section{Results}

Figure 1A investigates and confirms the wurtzite structure of prepared sample of $\mathrm{ZnO}$ nanoparticles, as we can see clearly, sample composed of only $\mathrm{ZnO}$ without any impurities, Peaks which appeared 
in the spectrum indicate that $\mathrm{ZnO}$ have good degree of crystallinity. Wurtzite $\mathrm{ZnO}$ related to the space group of [P6 $3 \mathrm{mc}$ ] number 186, with constants of $\mathrm{a}=3.12 \AA$ and $\mathrm{c}=5.30 \AA$ and the hexagonal structure. All peaks were identical to the standard structure of $\mathrm{ZnO}$ as compared with JCPDS card no. 36-1451.

The only characteristic peak appeared at a diffraction angle $2 \theta$ at $28.45^{\circ}$ of 5-Fluorouracil nanoparticles (Figure 1B). Figure 2 illustrates isotherms adsorption of $\mathrm{N}_{2}$ at $77 \mathrm{~K}$ on $\mathrm{ZnO}$ Nanoparticles, the adsorption isotherm are classified according to International Union of Pure and Applied Chemistry as type [IV] and (H1) hysteresis that closes at $\mathrm{P} / \mathrm{P}_{0}=0.324$ for $\mathrm{ZnO}$, this type of hysteresis which contains 2 branches that almost vertical and nearly over the range of gas uptake resulted from the existence of open cylindrical pores at both sides, this result is confirmed by the value of $[\mathrm{C}]$ constant 58.2 indicating the decrease in surface polarity, the specific surface area (ABET) of the prepared sample is about $=738.941 \mathrm{~m}^{2} / \mathrm{g}$ which was measured by using the BET equation. However, the total pore volume $(\mathrm{Vp})$ taken at a saturation pressure and expressed as liquid volume $=0.8176 \mathrm{cc} / \mathrm{g}$ and the average pore radius $=20.2 \AA$. Porosity detection is accomplished by constructing the V-t plot as shown in Figure 2, The correct choice of the reference data was judged through the agreement between the area calculated from the slope of the straight line passing through the origin in the plot and the area calculated from BET equation, the t-curve for pure $\mathrm{ZnO}$ shows a downward deviation revealing the micro pore filling with multilayer adsorption at low humidity reducing the surface available for continuous adsorption of pure $\mathrm{ZnO}$ samples, the pore size distributions of the samples were assessed by the Barret, Joyner and Halenda $[\mathrm{BJH}]$ method and represented in Figure 3, It is clearly observe formation of two peaks, the first one is centered at $24.5 \AA$ that belongs to supermicropores and the second one is broad centered at $30.9 \AA$ indicates a wide range of sample mesoporosity. Figure 3 shows the morphology of pure zinc oxide and [EDX] analysis is performed to investigate the elemental composition of $\mathrm{ZnO}$ Nanoparticles, the [EDX] spectrum exhibits intense peaks, which are associated with $\mathrm{O}$ and $\mathrm{Zn}$ atoms and no other elements appeared indicates high Purity of the prepared samples. Also it represents High resolution transmission electron microscope [HRTEM] of ZnO Nanoparticles.
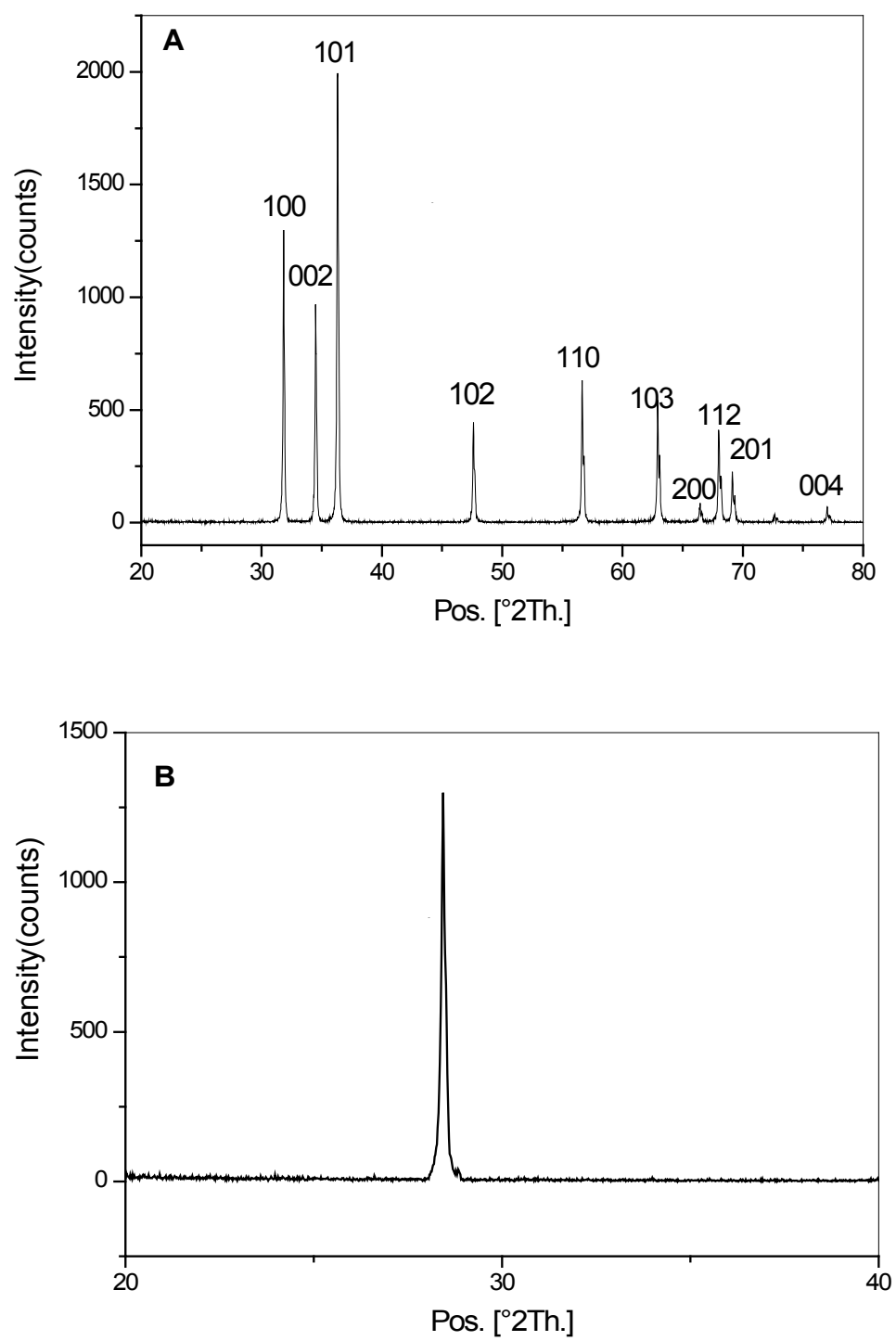

Figure 1: XRD pattern of $(\mathrm{A}) \mathrm{ZnO}$ and $(\mathrm{B})$ 5-FU nanoparticles. 
Citation: Sanad F, Nabih S, Goda MA (2018) A Lot of Promise for ZnO-5FU Nanoparticles Cytotoxicity against Breast Cancer Cell Lines. J Nanomed Nanotechnol 9: 486. doi: 10.4172/2157-7439.1000486

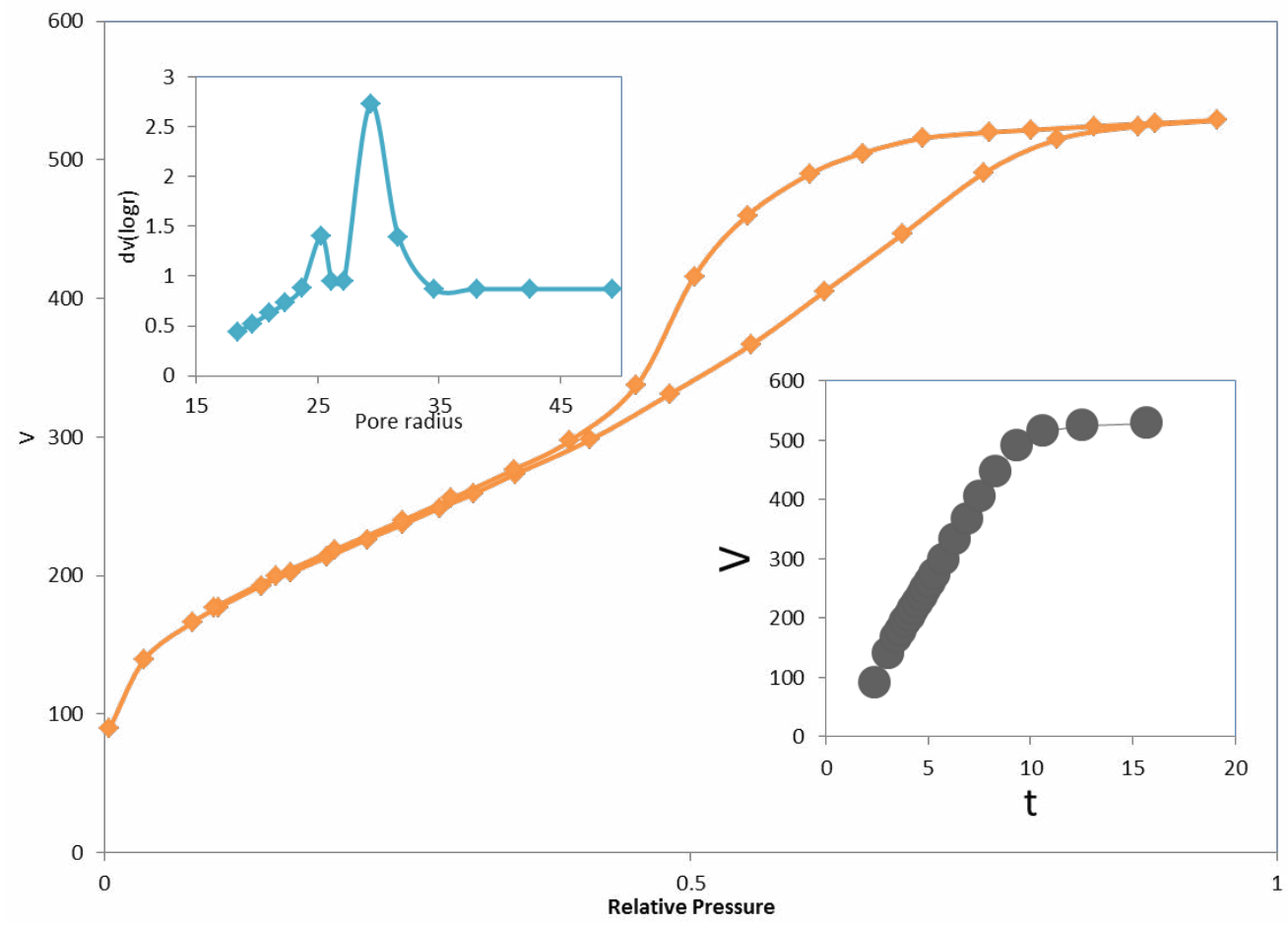

Figure 2: N2-adsorption-desorption isotherm, pore size distribution and V-t plot for ZnO Nanoparticles.
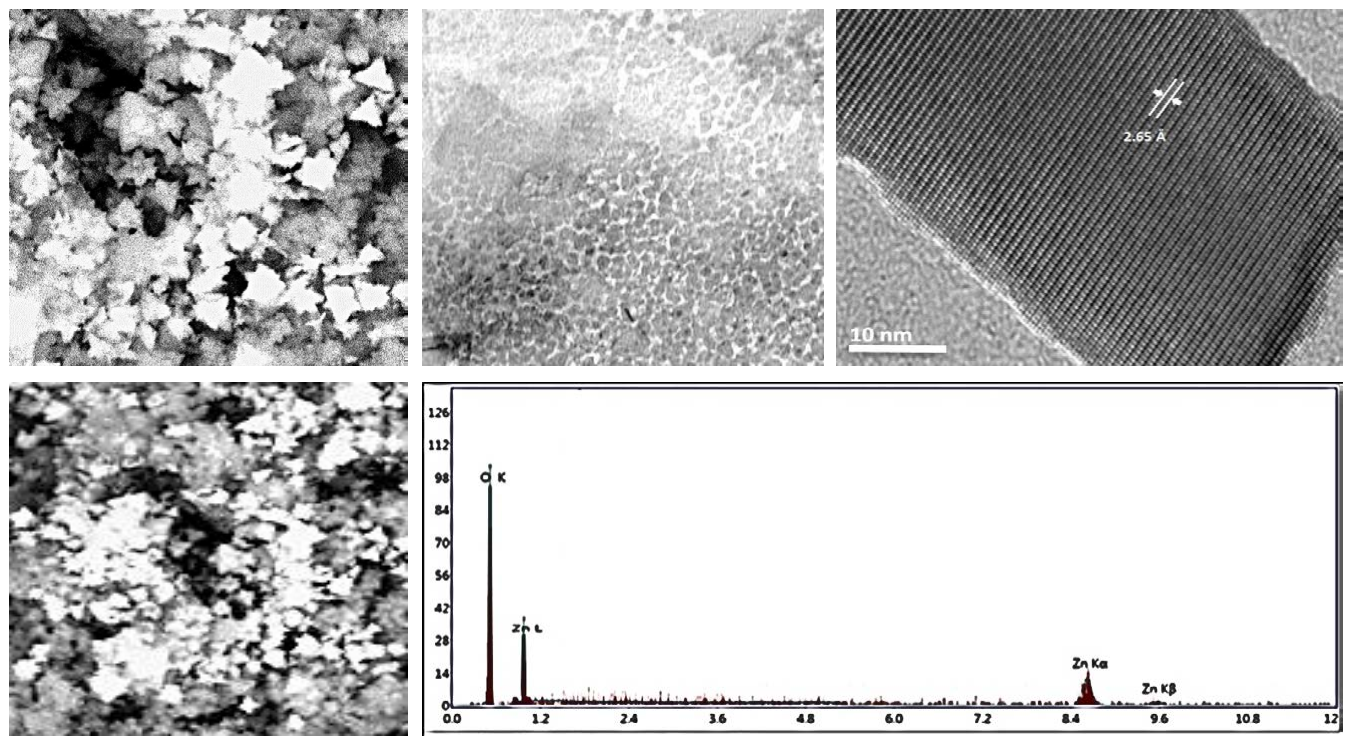

Figure 3: HRTEM, FESEM and EDX of ZnO.

Sample composed of large number of Nano flowery and hexagonal shapes of wurtzite $\mathrm{ZnO}$ that disperse through the whole sample matrix with homogeneous and ordered mesoporous structure. Figure 4 shows the scavenging radical activity of DPPH, where the arrangement of antioxidant activity of samples beginning with that can make the action with the most potent intensity as following, $\mathrm{ZnO}-5-\mathrm{FU}[7 \%]>\mathrm{ZnO}-5-$ $\mathrm{FU}[3 \%]>\mathrm{ZnO}-5-\mathrm{FU}[10 \%]>\mathrm{ZnO}-5-\mathrm{FU}[1 \%]>5-\mathrm{FU}>\mathrm{ZnO}$. The results of SOD and GPx assay confirm the previous results, so we can conclude from these results that $\mathrm{ZnO}-5-\mathrm{FU}[7 \%]$ has the highest antioxidant activities. Figure 5 shows the effect of $\mathrm{ZnO}-5-\mathrm{FU}$ samples on MCF7 cell viability and it represents a comparison of the cytotoxic effect between all samples after 72 hours of treatment, $\mathrm{ZnO}-5-\mathrm{FU}[7 \%]$ was significantly more cytotoxic than $\mathrm{ZnO}-5-\mathrm{FU}[3 \%]$ than $\mathrm{ZnO}-5-\mathrm{FU}[1 \%]$ than pure $5-\mathrm{FU}$ (P less than 0.002 ). $\mathrm{ZnO}-5-\mathrm{FU}[7 \%]$ was very cytotoxic at $0.16 \mu \mathrm{g} / \mathrm{ml}, \mathrm{ZnO}-5-\mathrm{FU}[3 \%]$ at $0.64 \mu \mathrm{g} / \mathrm{ml}$ compared to other samples, also Figure 5 illustrates calculated $\mathrm{IC}_{50}$ after performed in triplicate and results are reported as the mean \pm SEM. $\mathrm{P}<0.05$, compared with untreated cells and it found that $\mathrm{ZnO}-5-\mathrm{FU}[7 \%]$ has the lowest $\mathrm{IC}_{50}$ 

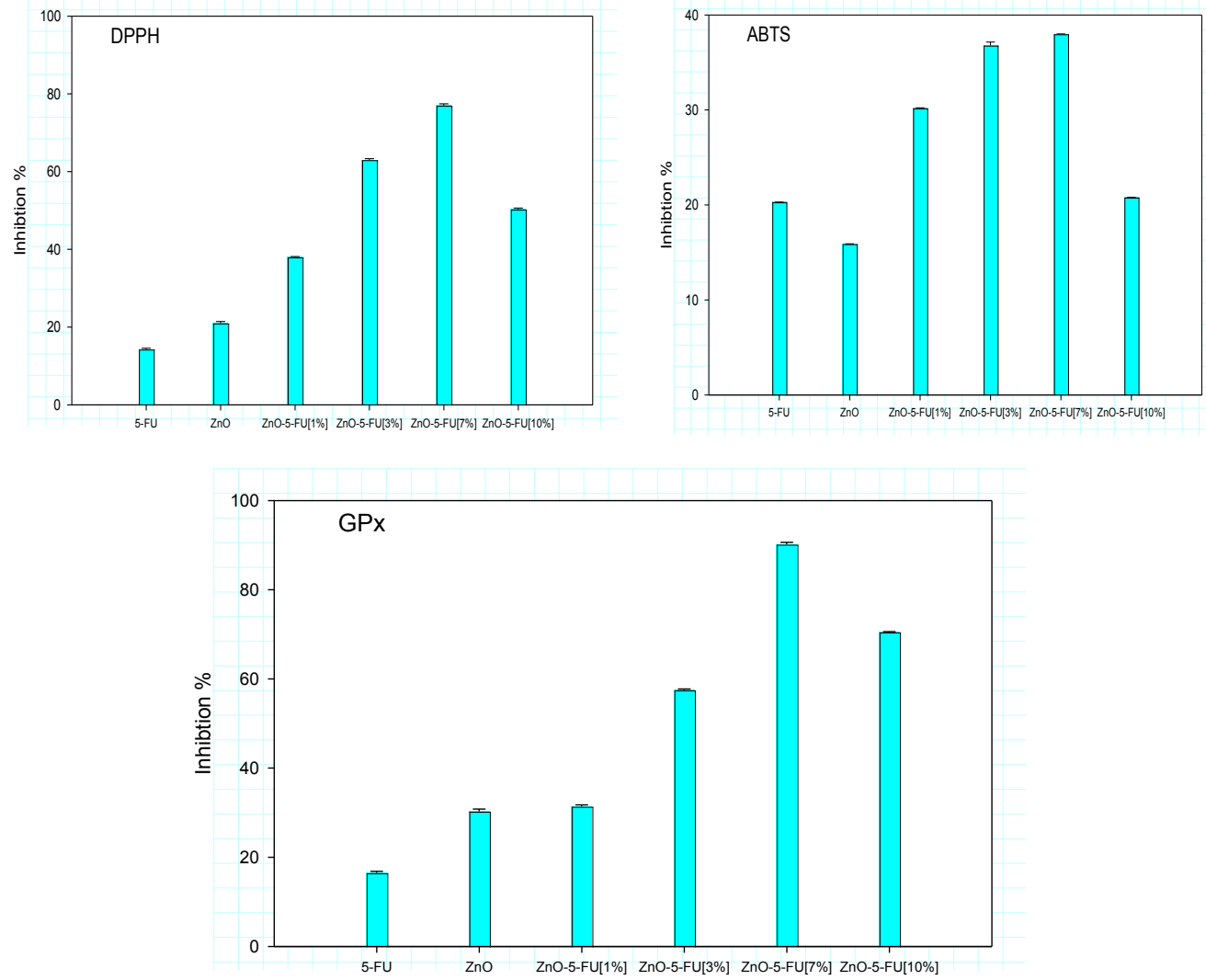

Figure 4: Inhibition\% of (A) DPPH free radical scavenging activity (B) SOD free radical scavenging activity for all fractions (D) GPx free radical scavenging activity for 5-FU, ZnO-5-FU prepared samples.
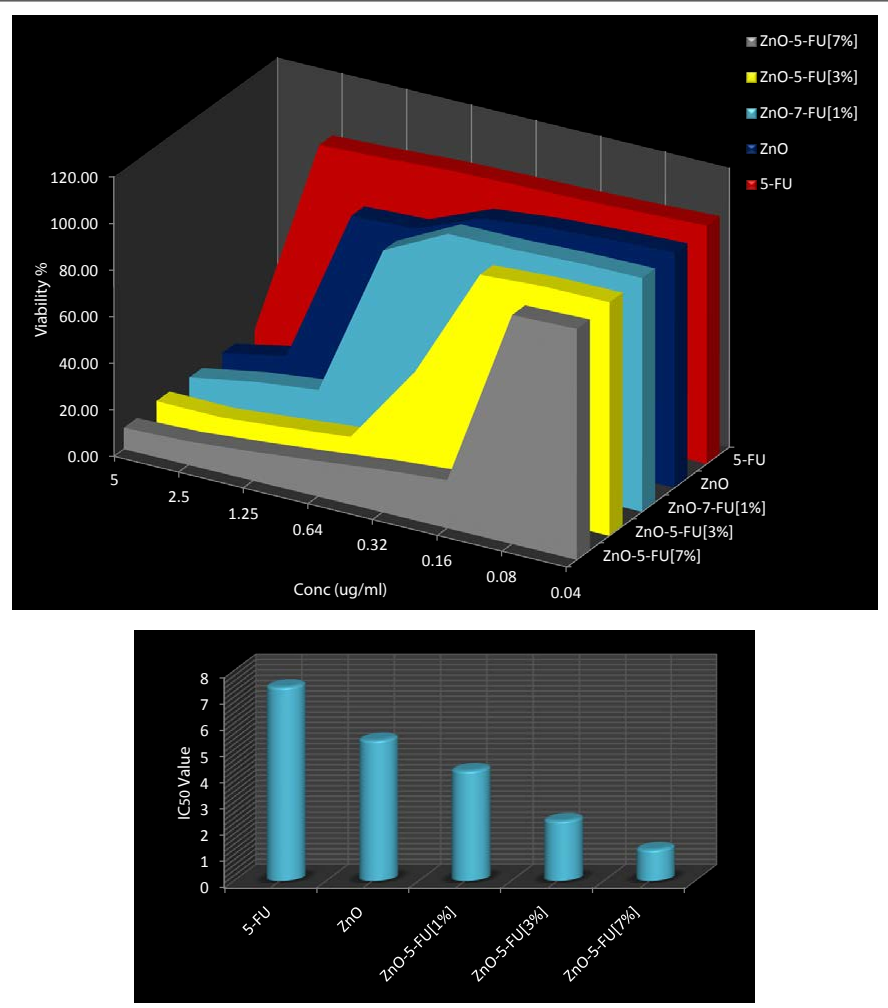

Figure 5: MTT assay analyzing the viability of MCF7 after treatment with 5-FU, ZnO-5-FU prepared samples, and Calculated IC ${ }_{50}$ of MCF7 after treatment with 5-FU, $\mathrm{ZnO}-5-\mathrm{FU}$ prepared samples, All tests were performed in triplicate and results are reported as the mean $\pm \mathrm{SEM}$. ${ }^{\mathrm{P}} \mathrm{P}<0.05$, compared with untreated cells. 
Citation: Sanad F, Nabih S, Goda MA (2018) A Lot of Promise for ZnO-5FU Nanoparticles Cytotoxicity against Breast Cancer Cell Lines. J Nanomed Nanotechnol 9: 486. doi: 10.4172/2157-7439.1000486

Page 6 of 8

values compared to other samples. After that, we investigated whether the prepared samples of $\mathrm{ZnO}-5-\mathrm{FU}$ induces apoptosis on MCF-7 cells and the results of flowcytometry [Annexin V-FITC] shows that observed decrease in the number of lived cells caused by apoptosis as shown in Figure 6a, apoptosis results of the prepared nanoparticles more than pure 5-FU, the most potent sample which has the biggest effect on the apoptotic induction is $\mathrm{ZnO}-5-\mathrm{FU}[7 \%]$. All types of phases of cell cycle were studied using DNA flowcytometry analysis. MCF7 cells were cultured in six-well plates for one day and treated with $\mathrm{ZnO}-5-\mathrm{FU}$ nanoparticles for 72 hours, after that DNA of the cells was analyzed by gel electrophoresis, it can be seen as shown in Figure $6 \mathrm{~b}$ that the cell cycle of MCF-7 arrested in the $G_{2} / M$ phase and decrease in $G_{1}$ phase which leads to increase in the apoptotic induction after treatment with nanoparticles for 72 hours. We can observe that the most potent apoptotic induction when the cells treated with $\mathrm{ZnO}-5$ $\mathrm{FU}[7 \%]$ and this reveals to the addition of $\mathrm{ZnO}$ nanoparticles to the 5 -FU drug increases the anticancer property of the drug. Many studies on treatment techniques that arrest the MCF-7 cell cycle at the $\left(\mathrm{G}_{0} /\right.$ $G_{1} . S$ and $\left.G_{2} / M\right)$ phases and then induces the apoptotic action. Hence the effect of $\mathrm{ZnO}-5-\mathrm{FU}$ was investigated to determine the mechanism of action of destroying of MCF-7 cells. RT-PCR investigation of gene expression of MCF-7 cancer cells treated with $\mathrm{ZnO}-5$-FU for 72 hours indicated the lowest value of Bcl-2, Her-2 in case of $\mathrm{ZnO}-5-\mathrm{FU}[7 \%]$ compared with the other prepared samples and the cancer cell control. It shows also an increase in the pre-apoptotic genes Bax and P-53 as shown in Figure 7.
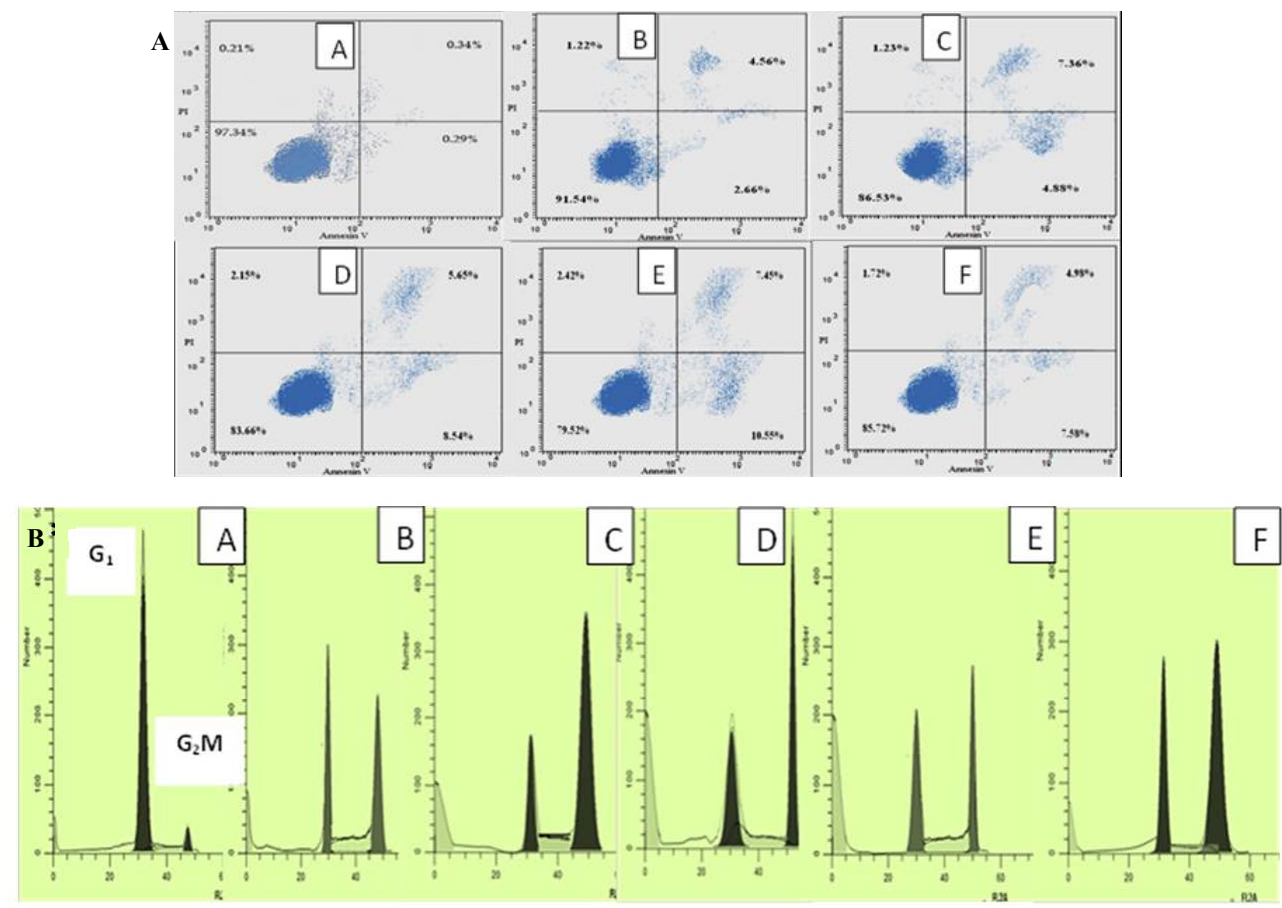

Figure 6: (a) The effect of 5-FU, ZnO and ZnO-5-FU prepared samples on MCF-7 cell apoptosis. Cells were incubated for 72 hours. Viable and dead cells were observed by [Annexin V-FITC] flowcytometry method (a) 5-FU (b) ZnO (c) ZnO-5-FU [1\%](d) ZnO-5-FU [3\%] (e) ZnO-5-FU [7\%] (f) ZnO-5-FU [10\%]. (b) Cell cycle analysis of (a) 5-FU (b) ZnO (c) ZnO-5-FU [1\%](d) ZnO-5-FU [3\%] (e) ZnO-5-FU [7\%] (f) ZnO-5-FU [10\%] which induces cell cycle arrest in MCF-7 after treatment for 72 hours. Flow cytometry analysis was performed for cell-cycle distribution. The DNA content was investigated with propidium iodide (PI) staining and florescence measured and analyzed. All tests were performed in triplicate and results are reported as the mean $\pm \mathrm{SEM}$. ${ }^{*} \mathrm{P}<0.05$, compared with untreated cells.

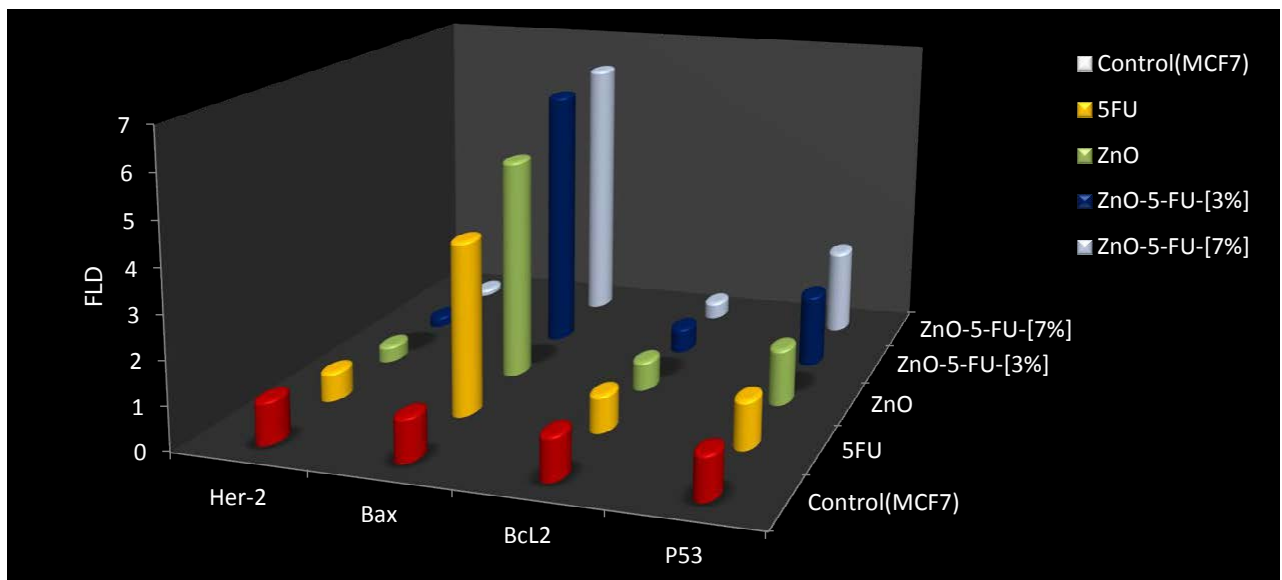

Figure 7: Expression levels of BaX, Her-2, BcL2 and P53 was determined by RT-PCR in MCF7 cell treated with (a) 5-FU (b) ZnO (c) ZnO-5-FU [1\%] (d) ZnO-5-FU [3\%] (e) ZnO-5-FU [7\%]. 


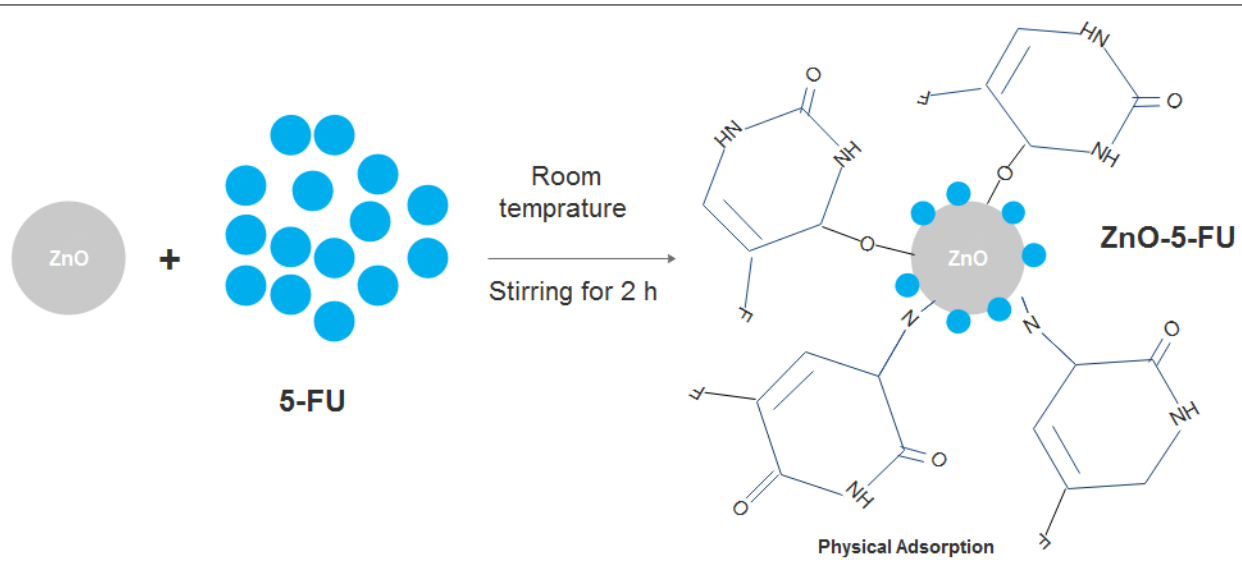

Figure 8: Scheme represents the combination between 5-FU and ZnO Nanoparticles.

\section{Discussion}

Novel route to modify anticancer properties of 5 -FU by incorporating $\mathrm{ZnO}$ nanoparticles on the surface of 5-FU as shown in Figure 8. As mentioned before $\mathrm{ZnO}-5-\mathrm{FU}$ anticancer activity returns to both 5-FU and $\mathrm{ZnO}$. 5-fluorouracil consists of uracil connected to fluorine atom in place of hydrogen atom. It penetrates cancer cell membrane and converted to many active metabolites such as fluorodeoxyuridine monophosphate (FdUMP) and fluorouridine triphosphate (FUTP), these active compounds affect DNA synthesis of the cancer cells and inhibit cell growth. Studies have shown that small zinc concentration in the cancer cells may be toxic against MCF7. Zinc oxide kills cancer cells through releasing reactive oxygen species (ROS) which inhibit cell growth. Nano - ZnO enhance permeability, electrostatic interaction and selective cytotoxicity due to increased ROS present in cancer cells. Incorporating $\mathrm{ZnO}$ into 5-FU surface increased the killing rate of cells with great extent. Radical scavenging study shows that antioxidant activity of $\mathrm{ZnO}-5-\mathrm{FU}$ greater than pure 5-FU and inhibition\% increased by increasing of the amount of $\mathrm{ZnO}$ incorporated until ratio reached $10 \%$ where the surface of 5-FU fully coated with $\mathrm{ZnO}$ Nanoparticles, anti-oxidant activity begun to decrease and this revealed to decreasing the free surface area of 5-FU. Apoptotic induction by Annexin V-FITC and Cell Cycle analysis confirms this results where the sample with highest potent of apoptotic induction was $\mathrm{ZnO}-5-\mathrm{FU}[7 \%]$ and decrease with decreasing $\mathrm{ZnO}$ amount through arrest in $G_{2} / M$ phase and decrease in $G_{1}$ phase. By investigating RT$\mathrm{PCR}$ results we can understand that $\mathrm{ZnO}-5-\mathrm{FU}$ decreases $\mathrm{Bcl}-2$, Her-2 and increases pre-apoptotic genes Bax and P-53 which intern induces apoptosis of the cells and decreases the cell viability as shown at MTT study.

\section{References}

1. Easton DF, Pharoah PD, Antoniou AC, Tischkowitz M, Tavtigian SV, et al (2015) Gene-panel sequencing and the prediction of breast-cancer risk. New England Journal of Medicine 372: 2243-2257.

2. Martin AM, Weber BL (2000) Genetic and hormonal risk factors in breast cancer. Journal of the National Cancer Institute 92: 1126-1135.

3. Willett W (1989) The search for the causes of breast and colon cancer. Nature 338: 389-394.

4. Morales L, Alvarez-Garriga C, Matta J, Ortiz C, Vergne Y, et al. (2013) Factors associated with breast cancer in Puerto Rican women. Journal of Epidemiology and Global Health 3: 205-215

5. Liu YT, Gao CM, Ding JH, Li SP, Cao HX, et al. (2011) Physiological, reproductive factors and breast cancer risk in Jiangsu province of China. Asian Pac J Cancer Prev 12: 787-790.
6. Diego EJ, McAuliffe PF, Soran A, McGuire KP, Johnson RR, et al. (2016) Axillary staging after neoadjuvant chemotherapy for breast cancer: a pilot study combining sentinel lymph node biopsy with radioactive seed localization of pre-treatment positive axillary lymph nodes. Annals of Surgical Oncology 23 1549-1553.

7. Swain SM, Ewer MS, Viale G, Delaloge S, Ferrero JM, et al. (2017) Abstract P4-21-41: Primary analysis of BERENICE: A phase II cardiac safety study of pertuzumab, trastuzumab, and neoadjuvant anthracycline-based chemotherapy in patients with locally advanced, inflammatory, or early-stage, unilateral, and invasive HER2-positive breast cancer. Cancer Research 77: 21-41.

8. Burstein HJ, Temin S, Anderson H, Buchholz TA, Davidson NE, et al. (2014) Adjuvant endocrine therapy for women with hormone receptor-positive breas cancer: American Society of Clinical Oncology clinical practice guideline focused update. Journal of Clinical Oncology 32: 2255-2269.

9. Drăgănescu M, Carmocan C (2017) Hormone Therapy in Breast Cancer. Chirurgia 112: 413-417.

10. den Hollander P, Savage MI, Brown PH (2013) Targeted therapy for breast cancer prevention. Front Oncol 3: 250.

11. Janni W (2016) Targeted Therapy of Breast Cancer. Oncology Research and Treatment 39: 100-101.

12. Coates A, Abraham S, Kaye SB, Sowerbutts T, Frewin C, et al. (1983) On the receiving end-patient perception of the side-effects of cancer chemotherapy. Eur J Cancer Clin Oncol 19: 203-208.

13. Grem JL (2000) 5-Fluorouracil: forty-plus and still ticking: A review of its preclinical and clinical development. Investigational New Drugs 18: 299-313.

14. Noordhuis $P$, Holwerda $U$, Van der Wilt CL, Van Groeningen CJ, Smid K, et al (2004) 5-Fluorouracil incorporation into RNA and DNA in relation to thymidylate synthase inhibition of human colorectal cancers. Ann Oncol 15: 1025-1032.

15. Cohen SS, Flaks JG, Barner HD, Loeb MR, Lichtenstein J (1958) the mode of action of 5-fluorouracil and its derivatives. Proc Natl Acad Sci USA 44: 1004-1012.

16. Eskandari MR, Moghaddam F, Shahraki J, Pourahmad J (2015) A comparison of cardiomyocyte cytotoxic mechanisms for 5-fluorouracil and its pro-drug capecitabine. Xenobiotica 45: 79-87.

17. Arias JL (2008) Novel strategies to improve the anticancer action of 5-fluorouracil by using drug delivery systems. Molecules 13: 2340-2369.

18. Boisdron-celle M, Menei PH, Benoit JP (1995) Preparation and Characterization of 5-Fluorouracil-loaded Microparticles as Biodegradable Anticancer Drug Carriers. J Pharm Pharmacol 47: 108-114.

19. Denizli A, Kiremitci M, Pişkin E (1989) Subcutaneous polymeric matrix system p (HEMA-BGA) for controlled release of an anticancer drug (5-fluorouracil): II: Release kinetics. Biomaterials 9: 363-366.

20. Zhuo RX, Du B, Lu ZR (1999) In vitro release of 5-fluorouracil with cyclic core dendritic polymer. J Control Release 57: 249-257.

21. Sato S, Itamochi H, Kigawa J, Oishi T, Shimada M, et al. (2009) Combination chemotherapy of oxaliplatin and 5-fluorouracil may be an effective regimen for 
Citation: Sanad F, Nabih S, Goda MA (2018) A Lot of Promise for ZnO-5FU Nanoparticles Cytotoxicity against Breast Cancer Cell Lines. J Nanomed Nanotechnol 9: 486. doi: 10.4172/2157-7439.1000486

Page 8 of 8

mucinous adenocarcinoma of the ovary: a potential treatment strategy. Cancer Sci 100: 546-551.

22. Chandran SP, Natarajan SB, Chandraseharan S, Shahimi MS (2017) Nano drug delivery strategy of 5-fluorouracil for the treatment of colorectal cancer. Journal of Cancer Research and Practice. 4: 45-48.

23. Bassiouni $Y$, Faddah L (2012) Nanocarrier-Based Drugs: The Future Promise for Treatment of Breast Cancer. Journal of Applied Pharmaceutical Science 2: 225-232.

24. Bagalkot V, Zhang L, Levy-Nissenbaum E, Jon S, Kantoff PW, et al. (2007) Quantum dot-aptamer conjugates for synchronous cancer imaging, therapy, and sensing of drug delivery based on bi-fluorescence resonance energy transfer. Nano Lett 7: 3065-3070.

25. He C, Lu K, Liu D, Lin W (2014) Nanoscale metal-organic frameworks for the co-delivery of cisplatin and pooled siRNAs to enhance therapeutic efficacy in drug-resistant ovarian cancer cells. J Am Chem Soc 136: 5181-5184.

26. Pan L, He Q, Liu J, Chen Y, Ma M, et al. (2012) Nuclear-targeted drug delivery of TAT peptide-conjugated monodisperse mesoporous silica nanoparticles. J Am Chem Soc 134: 5722-5725.

27. Rasmussen JW, Martinez E, Louka P, Wingett DG (2010) Zinc oxide nanoparticles for selective destruction of tumor cells and potential for drug delivery applications. Expert Opin Drug Deliv 7: 1063-1077.

28. Shi J, Votruba AR, Farokhzad OC, Langer R (2010) Nanotechnology in drug delivery and tissue engineering: from discovery to applications. Nano Lett 10 3223-3230.

29. Aydin R, Pulat M (2012) 5-Fluorouracil encapsulated chitosan nanoparticles for $\mathrm{pH}$-stimulated drug delivery: evaluation of controlled release kinetics. Journal of Nanomaterials.

30. Sirelkhatim A, Mahmud S, Seeni A, Kaus NH, Ann LC, et al. (2015) Review on zinc oxide nanoparticles: antibacterial activity and toxicity mechanism. NanoMicro Letters 7: 219-242.

31. Spanhel L (2006) Colloidal $\mathrm{ZnO}$ nanostructures and functional coatings: A survey. Journal of sol-gel science and technology 39: 7-24. 